\section{Analisis Yuridis Pemberian Hibah Dibawah Tangan Dikaitkan Dengan Pendaftarannya Pada Kantor Pertanahan Terhadap Penetapan Pengadilan Agama Medan Kelas I-A Nomor: 125/Pdt.P/2017/PA.Mdn}

oleh:

\section{Kharisman Koima Batubara}

\section{Abstrak}

Hibah adalah salah satu peralihan hak milik yang telah di atur dalam Kitab UndangUndang Hukum Perdata. Pengertian hibah sebagaimana dijelaskan dalam ketentuan Pasal 1666 KUH Perdata adalah Sesuatu persetujuan dengan mana si penghibah di waktu hidupnya, dengan Cuma-Cuma dan dengan tidak dapat ditarik kembali, menyerahkan suatu benda guna keperluan si penerima hibah yang menerima penyerahan itu, Hibah juga merupakan salah satu ibadah yang bertujuan untuk mempererat rasa kasih sayang antara penghibah dan si penerima hibah.

Berdasarkan hasil penelitian dapat diperoleh Permasalahan dalam penelitian ini adalah Proses peralihan hak atas tanah tidak dapat dilakukan karena pemberian hibah dilakukan dengan cara hibah dibawah tangan dan pemberi hibah telah meninggal dunia sebelum proses peralihan di lakukan dihadapan notaris..

Hal itu terjadi dikarenakan kurangnya pemahaman hukum tentang prosedur hibah tanah sesuai perundang-undangan dan sudah menjadi kebiasaan mereka tunduk pada hukum adat yang diperbolehkan melakukan hibah dibawah tangan tanpa dilakukan dihadapan Notaris dan hibah menjadi tidak sah bila tidak dilakukan dihadapan Notaris kecuali bagi mereka yang tunduk pada hukum adat. Pada dasarnya hibah menjadi sah dan akibatnnya berlaku bagi para pihak jika penerimaan hibah telah menerima dengan tegas pemberian tersebut (dengan akta notaris) hal ini diatur dalam pasal 1683 jo, pasal 1682 Kitab UndangUndang Hukum, Berdasarkan hibah dibawah tangan yang pemberi hibahnya telah meninggal dunia terlebih dahulu sebelum proses peralihan hak secara peraturan perundang-undangan maka diperlukan putusan pengadilan agama agar peralihan tanah tersebut dapat dilakukan.

Kata Kunci: Tanah, Hibah dibawah tangan, Notaris

\section{Abstract}

Grant is one of the transitions of property rights that have been regulated in the Code of Civil Law. The definition of a grant as explained in the provisions of Article 1666 of the Civil Code is something of an agreement with which the donor in his lifetime, free of charge and irrevocably, hand over an object for the purpose of the recipient of the grant who received the surrender. Grant is also one of worship that aims to strengthen the sense of affection between the donor and the recipient of the grant.

This type of research is library research by discussing books, both primary and secondary books that explain the concepts of civil law and Islamic law. Meanwhile, this research is comparative descriptive with normative approach. The research method used in this paper is normative-empirical legal research. The data used are secondary data and primary data derived from books, or legal literature, legislation, interviews and other materials that are included in the scope of the grant.

Based on the results of the study, it can be obtained that the problem in this study is about the process of transitions the land rights cannot be carried out because the giving of the grant is done by means of a grant under the hand and the grantor has passed away before the transition process is done before a Notary.

This is due to the lack of legal understanding of the procedure for land grants in accordance with the law and it has become their custom to comply with customary law which is allowed to do underhand grants without being done before a Notary and the grant is invalid if it is not done before a Notary except for those who are subject to customary law. Basically the grant is valid and consequently it applies to the parties if the receipt of the grant has received explicitly the gift (with a Notarial deed) this is regulated in article 1683, article 1682 of the Law Code. Based on the underhand grant of the donor who has died first before the transitions process of the rights in the legislation, a religious court decision is needed so that the transitions of land can be carried out.

Keywords: Land, Underhand Grant, Notary 
Media Komunikasi dan Informasi Hukum dan Masyarakat

\section{PENDAHULUAN}

\section{A. Latar Belakang.}

Pembuatan akta hibah harus dilakukan di hadapan pejabat yang berwenang terhadap pembuatan akta tersebut, hal ini sesuai dengan ketentuan yang terdapat di dalam pasal 1682 KUHPerdata. Jabatan notaris kehadirannya dikehendaki dalam hukum yang memiliki tujuan untuk membantu serta melayani masyarakat yang memerlukan alat bukti tertulis bersifat otentik terkait dengan tanah mengenai keadaan, peristiwa atau perbuatan hukum. ${ }^{1}$

Dalam KUHPerdata telah dijelaskan bahwa hibah yang telah diberikan tidak dapat ditarik kembali. Namun pemberi hibah dapat mengajukan gugatan pembatalan hibah apabila penerima hibah telah melakukan hal-hal seperti yang tercantum alam pasal 1688 KUHPerdata. ${ }^{2}$

Hibah adalah pemberian yang dilakukan oleh seseorang kepada pihak lain yang dilakukan ketika masih hidup dan pelaksanaan pembagiannya dilakukan pada waktu penghibah masih hidup juga. Biasanya pemberian pemberian tersebut tidak akan pernah dicela oleh sanak keluarga yang tidak menerima pemberian itu, oleh karena pada dasarnya seseorang pemilik harta kekayaan berhak dan leluasa untuk memberikan harta bendannya kepada siapapun.

Dalam penetapan Pengadilan Agama Medan, Nomor 125/Pdt.P/2017/PA.Md, yang mana pemohon mengajukan permohonan penetapan hibah pada tanggal 22 November 2017. Pemohon adalah ahli waris sah dari Almarhum Buyung Tanjung Bin Harun Tanjung dan benar saudara kandung (adik kakak). Pemohon benar telah menerima hibah dari

${ }^{1}$ Habib Adjie, Hukum Notaris Indonesia, Refika Aditama, Bandung 2009, hal 73.

${ }^{2}$ Pasal 1688 KUHPerdata kakaknya Buyung Tanjung berupa sebidang tanah beserta bangunan rumah diatasnya dalam bentuk hibah yang letak dan luas harta hibah tidak lebih dari 1/3 harta milik Buyung Tanjung dan atas persetujuan dari persetujuan dari ahli waris lainnya, Pemohon telah menerima telah menerima hibah tersebut pada tanggal 10 Agustus 2002.

Bahwa pada tanggal 11 November 2003 Buyung Tanjung bin Harun Tanjung meninggal dunia di Kuala Lumpur, Malaysia karena sakit. Karena harta yang dihibahkan tersebut dalam sertifikatnya masih atas Nama Buyung Tanjung/Pemberi hibah dan pemberian hibah dilakukan dengan surat materai bukan dihadapan Notaris, Maka untuk keperluan balik nama sertifikat harta hibah atas nama pemohon diperlukan penetapan dari pengadilan Agama Medan.

Saat penerima hibah ingin melakukan balik nama dikantor Badan pertanahan Nasional, penerima hibah ditolak dikarenakan masih ada syarat syarat ketentuan yang belum dilengkapi,karna untuk balik nama yang pemberi hibahnnya sudah meninggal haruslah memiliki surat penetapan pengadilan dan akta Notaris yang sudah di sahkan menurut Undang-undang pasal 1666-1693 Kitab Undang-undang Hukup Perdata.

\section{B. Rumusan Masalah.}

Berdasarkan uraian pada bagian latar belakang diatas, maka beberapa hal yang menjadi pokok permasalah dalam penelitian dan dibahas secara lebih mendalam pada penelitian ini sebagai berikut:

1. Kedudukan hukum terhadap hibah yang diberikan berdasarkan pemberian hibah dibawah tangan? 
Media Komunikasi dan Informasi Hukum dan Masyarakat

2. Bagaimana hukum terhadap hak atas tanah yang dialihkan dengan hibah dibawah tangan?

3. Bagaimana pendaftaran hibah pada kantor pertanahan yang bersumber dari hibah dibawah tangan?

\section{Tujuan Penelitian.}

Berkaitan dengan permasalahan tersebut diatas, maka tujuan yang hendak dicapai dalam penelitian ini adalah

1. Untuk menganalisa putusan yang dilakukan oleh Pengadilan dalam melindungi penerima hibah.

2. Untuk menganalisa ketentuan hukum bila pemberi hibah sudah meninggal dunia.

3. Untuk menganalisa kekuatan hukum bila pemberian hibah dilakukan dihadapan notaris.

\section{Manfaat Penelitian.}

Berdasarkan permasalahan dalam penelitian dan tujuan ini dapat dikaji hendaknya dicapai dan diharapkan dapat memberikan mamfaat yang berguna sebagai berikut :

1. Teoritis.

Secara teoritis, penelitian ini diharapkan dapat memberikan sumbangan terhadap kalangan akademis sebagai bahan pengkajian dan menganalisa lebih lanjut serta menambah khasanah ilmu kenotariatan tentang perkembangan penelitian hukum, khususnya yang berkaitan dengan Akta Hibah.

2. Praktis.

Dari segi praktis penelitian ini dapat memberikan pemahaman dan pedoman bagi diri sendiri atau sebagaai bahan kajian didalam praktisi hukum dalam menyelesaikan pekara akta hibah dibawah tangan sehingga tidak ada salah satu pihak yang merasa dirugikan dalam pengembangan lebih lanjut.

\section{E. Keaslian Penelitian.}

Ada beberapa penelitian yang menyangkut masalah akta hibah namun permasalahan dan bidang kajiannya berbeda, diantarannya penelitian yang dilakukan oleh :

1. Prastowo Hendarsanto, SH NIM: 134130041611. Mahasiswa Magister Kenotariatan, Universitas Diponegoro Semarang, dengan judul tesis Studi Perbandingan Tentang hubungan hibah Dengan Waris menurut Kompilasi Hukum Islam dan Kitab, (Studi kasus dikota Semarang). Dengan permasalahan yang dibahas.

2. Lila Triana, NIM. 027011035, Mahasiswa Magister Kenotariatan, Universitas Sumatera Utara, Tahun 2004, dengan judul tesis "Hibah Keepada Anak Angkat Dalam Perspektif Hukum Islam dan Hukum Adat (studi kasus di Kota Medan)". Dengan permasalahan yang dibahas :

3. Triyana Ratih, NIM. 157011038, Mahasiswa Magister Kenotariatan, Universitas Sumatera Utara, dengan judul tesis "Analisis Yuridis Hibah Yang Diperhitungkan Sebagai Warisan Dari Orang Tua Kepada Anak Menurut Kompilasi Hukum Islam Berdasarkan Putusan Mahkamah Agung Republik Indonesia Nomor 10 PK/AG/2006.". Dengan permasalahan yang dibahas :

4. Merry N, Sinaga, NIM. 057011056, Mahasiswa Magister Kenotariatan, Universitas Sumatera Utara, dengan judul tesis " Tinjauan Yuridis Terhadap Kekuatan 
Media Komunikasi dan Informasi Hukum dan Masyarakat

Pembuktian Akta Dibawah Tangan Yang

Telah Dilegalisasi dan Waarmerking Oleh Notaris."

Dari Judul Penelitian tersebut tidak ada kesamaan dengan penelitian yang penulis lakukan. Dengan demikian judul ini belum ada yang membahasnya sehingga penelitian ini dijamin keasliannya dan dapat dipertanggungjawabkan secara ilmiah.

\section{F. Kerangka Teori dan Konsepsi}

\section{Kerangka Teori}

Teori adalah untuk menerangkan atau menjelaskan mengapa gejala spesifik atau proses tertentu terjadi, ${ }^{3}$ dan suatu teori harus diuji dengan menghadapkannya pada faktafakta yang dapat menunjukkan ketidak benarannya. ${ }^{4}$ Kerangka teori adalah kerangka pemikiran atau butir-butir pendapat,teori, tesis mengenai suatu kasus atau permasalahan (problem) yang menjadi bahan perbandingan atau pegangan teoritis dalam penelitian. ${ }^{5}$

Di dalam suatu teori sedikitnya terdapat tiga unsur, yaitu :

1. penjelasan mengenai hubungan antara berbagai unsur dalam suatu teori.

2. teori menganut sistem deduktif, yaitu bertolak dari suatu yang umum yang abstrak menuju suatu yang khusus dan nyata.

3. teori memberikan suatu penjelasan atau gejala yang dikemukakannya.

Fungsi teori dalam suatu penetian adalah untuk memberikan pengarahan kepada penelitian yang akan dilakukan. Hukum merupakan sarana untuk mengatur kehidupan sosial.

3 JJ M, Wuisman, dengan menyunting M. Hisyam, Penelitian IImu-IImu Sosial, (jilid I), Jakarta, FE UI,1996, hal.203

4 Ibid, hal. 16

${ }^{5}$ M. Solly Lubis, op. cit, hal. 80.
Perlindungan hukum harus melihat tahapan yakni perlindungan hukum lahir dari suatu ketentuan hukum dan segala peraturan hukum yang diberikan oleh masyarakat yang pada dasarnya merupakan kesepakatan masyarakat tersebut untuk mengatur hubungan perilaku antara anggota-anggota masyarakat dan antara perseroan dengan pemerintah yang dianggap mewakili kepentingan masyarakat. Suatu akta memiliki kekuatan bukti otentik, maka haruslah ada kewenangan dari Pejabat Umum yang dalam hal ini Notaris, untuk membuat akta otentik yang bersumber dari Undang Undang. ${ }^{6}$

Selain menggunakan teori positif hukum dari Jhon Austin dalam menganalisis tesis ini, juga cenderung digunakan teori sistem yang dikemukakan Mariam Darus Badrulzaman, bahwa sistem adalah kumpulan asas-asas hokum yang terpadu, yang merupakan landasan di atas mana dibangun tertib hukum. ${ }^{7}$

Dengan demikian, pembentukan hukum dalam bentuk hukum positif harus berorientasi pada asas-asas hukum sebagai jantung peraturan hukum tersebut. ${ }^{8}$ Hibah diatur oleh Pasal 1666 KUH Perdata, dan merupakan tindakan persetujuan dari si pemberi hibah pada waktu hidupnya, dengan cuma-cuma dan tidak dapat ditarik kembali untuk menyerahkan sesuatu benda guna keperluan si penerima hibah. Undang-undang mengakui hibah yang terjadi diantara orang-orang yang masih hidup. Akta hibah berdasarkan Pasal 1682 harus dibuat di muka Notaris.

6 Andy, Hukum Koperasi dan Peran Notaris Di Indonesia, Yogyakarta, 2005, hal.30

${ }^{7}$ Mariam Darus Badrulzaman, Mencari Sistem Hukum Benda Nasional, Alumni, Bandung,1983, hal.15

${ }_{8}$ Lihat, Satjipto Rahardjo, IImu Hukum, Alumni, Bandung, 1986, hal.15 
Media Komunikasi dan Informasi Hukum dan Masyarakat

Pasal 1667 KUH Perdata, menyebutkan penghibahan hanya boleh dilakukan terhadap barang-barang yang sudah ada pada saat penghibahan itu terjadi. Jika hibah itu mencakup barang-barang yang belum ada, maka penghibahan batal sekedar mengenai barangbarang yang belum ada. Selanjutnya Pasal 1668, menyatakan penghibah tidak boleh menjanjikan bahwa ia tetap berkuasa untuk menggunakan hak miliknya atas barang yang dihibahkan itu; penghibahan demikian, sekedar mengenai barang itu, dipandang sebagai tidak sah.

Hibah yang diberikan pada saat pemberi hibah dalam keadaan sakit yang dekat dengan kematian, maka harus mendapat persetujuan dari ahli warisnya. ${ }^{9}$ Selain itu bagi warga negara Indonesia yang berada di negara asing juga dapat membuat surat hibah di hadapan Konsulat atau Kedutaan Republik Indonesia setempat sepanjang isinya tidak bertentangan dengan ketentuan pasal-pasal dalam $\mathrm{KHI}$ tersebut. ${ }^{10}$

\section{Konsepsi}

Konsepsi adalah salah satu bagian terpenting dari teori, Peranan konsep dalam penelitian adalah untuk menghubungkan dunia teori dan observasi, antara abstrasi dan realita. ${ }^{11}$ Konsep diartikan sebagai kata yang menyatakan abstraksi yang digeneralisassikan dari hal-hal yang khusus, yang disebut dengan definisi operasional. ${ }^{12}$

\footnotetext{
${ }^{9}$ Pasal $213 \mathrm{KHI}$

10 Pasal 214

${ }^{11}$ Masri Singarimbun dan sifian effendi, Metode Penelitian Survei, Jakarta, LP3ES, 1989

12 Sumadi Suryabrata, Metode Penelitian, Jakarta, Raja Grafindo Persada, 1998, hal.3.
}

Pentingnya definisi adalah untuk menghindari pengertian atau penafsiran yang berbeda dari satu istilah yang dipakai. Oleh karena itu, berdasarkan kerangka teori yang telah diuraikan di atas, dalam penulisan tesis ini di uraikan serangkaian definisi sebagai berikut :

a. Notaris adalah pejabat umum yang berwewenang untuk membuat akta otentik dan kewenangan lainnya sebagai yang dimaksud dalam Undang-undang jabatan notaris Nomor 2 Tahun 2014 pada pasal 1 angka1. ${ }^{13}$

b. Hibah adalah pemberian yang dilakukan oleh seseorang kepada pihak lain yang dilakukan ketika masih hidup dan pelaksanaan pembagiannya dilakukan pada waktu penghibah masih hidup juga.

c. Akta Hibah Notaris adalah surat perjanjian yang diketahui dan dibuat oleh seorang Notaris yang dimana pemberian yang dilakukan oleh seseorang kepada pihak lain yang dilakukan ketika masih hidup dan pelaksanaan pembagiannya dilakukan pada waktu penghibah masih hidup juga.

d. Hibah Dibawah Tangan adalah surat perjanjian yang dibuat diatas materai atau kertas segel yang dimana pemberian yang dilakukan oleh seseorang kepada pihak lain yang dilakukan ketika masih hidup dan pelaksanaan pembagiannya dilakukan pada waktu penghibah masih hidup juga dan juga saksi-saksi ditunjuk langsung oleh pemberi hibah.

e. Penetapan Pengadilan adalah salah satu merupakan putusan pertama dan terakhir sehingga upaya hukum banding tidak dapat dilakukan terhadap penetapan.

${ }^{13}$ Pasal 1 angka 4 Kode Etik Notaris 
Media Komunikasi dan Informasi Hukum dan Masyarakat

\section{G. Metode Penelitian}

Metode berasal dari bahasa Yunani Methods yang berarti tata cara atau jalan, Sehubungan dengan penelitian ilmiah, maka metode dalam hal ini menyangkut tentang cara kerja yaitu cara kerja yang berfungsi untuk dapat memahami objek yang menjadi sasaran ilmu yang bersangkutan. ${ }^{14}$

Karya tulis termasuk penelitian ini dipengaruhi oleh keakuratan data yang diperoleh untuk mendapatkan hasil yang optimal dalam melengkapi bahan bahan dalam penelitian. Metode yang diterapkan dalam suatu penelitian adalah kunci utama untuk menilai baik buruknnya suatu penelitian. Metode ilmiah inilah yang akan menetapkan alur kegiatan dalam penelitian ini, mulai dari pemburuan data sampai kepada penyimpulan suatu kebenaran yang diperoleh dalam penelitian ini. ${ }^{15}$

\section{Jenis dan Sifat Penelitian}

Penelitian ini bersifat deskriptif, yaitu suatu penelitian yang menggambarkan, menelaah, menjelaskan dan menganalisis hukum baik dalam bentuk teori maupun praktek pelaksanaan dari hasil penelitian, ${ }^{16}$ dalam hal ini pemberian hibah dibawah tangan kepada saudara kandung. Penelitian ini dilakukan melalui pendekatan peraturan perundangundangan, khususnya yang menyangkut hibah dan pewarisan atas kasus putusan pengadilan Agama tentang kedudukan hibah. Jadi, sifat penelitian ini adalah juridis normatif, yaitu

\footnotetext{
14 Koenjaraningrat, Metode-metode Penelitian Masyarakat, Jakarta, Gramedia, 1997, hal.16

15 Tanpil Ansari Siregar, Metodologi Penelitian Hukum, Medan, Medan Grafika, 2004, hal.15.

16 Soerjono Soekanto, Pengantar Penelitian Hukum, UI Press, Jakarta, 1986, hal.64
}

penelitian kepustakaan atau studi dokumen yang dilakukan atau ditujukan hanya pada peraturan-peraturan yang tertulis atau bahan hukum yang lain. ${ }^{17}$

\section{Sumber Data}

Pengumpulan data diperoleh dari penelitian kepustakaan yang didukung penelitian lapangan, sebagai berikut:

1) Bahan hukum primer, yaitu data yang langsung dikumpulkan oleh peneliti dari sumber pertamanya. ${ }^{18}$ Adapun yang menjadi sumber dari bahan-bahan hukum yang mengikat, yakni:

a) Kitab Undang-Undang Hukum Perdata.

b) Undang-Undang Nomor 24 Tahun 1997

c). Peraturan Pemerintah Nomor 9 Tahun 1975 tentang Peraturan Pelaksanaan Undang-Undang Nomor 1 Tahun 1974.

d). Instruksi Presiden Nomor 1 Tahun 1991 tentang Kompilasi Hukum Islam.

2) Bahan hukum sekunder adalah bahan hukum yang memberikan penjelasan mengenai bahan hukum primer, seperti: hasil-hasil penelitian dan karya ilmiah dari kalangan hukum, yang berkaitan harta yang dihibahkan dibawah tangan.

3) Bahan tertier adalah bahan pendukung di luar bidang hukum seperti kamus ensiklopedia atau majalah yang terkait dengan hibah dibawah tangan..

${ }^{17}$ Bambang Waluyo, Metode Penelitian Hukum, Sinar Grafika, Jakarta, 1996, hal.13

18 Suharsimi Arikunto Prosedur penelitian suatu pendekatan praktik, hal.129 
Media Komunikasi dan Informasi Hukum dan Masyarakat

\section{Teknik dan Pengumpulan Data}

Teknik ini menggunakan 2 jenis yaitu

1. Penelitian kepustakaan (library research) yaitu menghimpun data dengan melakukan penelaahan bahan kepustakaan atau data sekunder yang meliputi bahan hukum primer, bahan hukum sekunder dan bahan hukum tertier. ${ }^{19}$

2. Penelitian lapangan (Field reseach) untuk mendapatkan data yang terkait dengan masalah pemberian hibah dibawah tangan , dengan melakukan wawancara kepada :

a. Notaris dikota Medan

b. Penerima hibah

Penelitian ini menggunakan 2 (dua) alat pengumpulan data yaitu:

1. Studi Dokumen untuk mengumpulkan data sekunder yang terkait dengan permasalahan yang diajukan, dengan cara mempelajari buku-buku, hasil penelitian dan dokumen-dokumen perundang-undangan dalam kaitan dengan harta yang dihibahkan selanjutnya digunakan untuk kerangka teoritis pada penelitian.

2. Pedoman wawancara, yang dilakukan dengan pedoman wawancara yang terstruktur kepada nara sumber yang telah ditetapkan tentang harta yang dihibahkan dibawah tangan.

\section{Kualitatif}

Kualitatif data yang digunakan dalam penelitian tesis ini adalah analisis data kualitatif, yaitu analisis data yang tidak mempergunakan angkaangka tetapi berdasarkan atas peraturan perundang-undangan, pandangan-pandangan

${ }_{19}$ Soerjono Soekanto dan Sri Mamudji, Penelitian Hukum Normatif Suatu Tinjauan Singkat, Rajawali Press, Jakarta, 1995, hal.39. narasumber hingga dapat menjawab permasalahan dari penelitian ini. Semua data yang diperoleh disusun secara sistematis, diolah dan diteliti serta dievaluasi. Kemudian data dikelompokkan atas data yang sejenis, untuk kepentingan analisis, sedangkan evaluasi dan penafsiran dilakukan secara kualitatif yang dicatat satu persatu untuk dinilai kemungkinan persamaan jawaban.

\section{A. Kedudukan Hukum Terhadap Hibah Yang Diberikan Berdasarkan Pemberian Hibah Dibawah Tangan}

\section{Pengaturan Pemberian Hibah Menurut Ketentuan Yang Berlaku}

\subsection{Menurut KUHP}

Pengertian menurut Kitab undangundang Hukum Perdata Istilah hibah menurut Pasal 1666 Kitab Undang-Undang hukum Perdata (disebut KUHPerdata), adalah " Sesuatu persetujuan dengan mana si penghibah di waktu hidupnya, dengan Cuma-Cuma dan dengan tidak dapat ditarik kembali, menyerahkan suatu benda guna keperluan si penerima hibah yang menerima penyerahan itu " dari Pasal 1666 KUHPerdata dapat dilihat unsur dalam hibah, antara lain:

1. Hibah dilakukan pada waktu Si Pemberi Hibah masih hidup.

2. Hibah dilakukan dengan cuma-Cuma.

3. Hibah tidak dapat ditarik kembali

Fungsi akta notaris dalam hibah bukan semata-mata sebagai alat bukti, tapi juga sebagai syarat esensial untuk sahnya persetujuan hibah. Karena itu hibah yang tak diperbuat dengan akta notaris, atau hibah yang diperbuat dengan cara bebas di luar akta notaris, adalah persetujuan hibah yang mutlak batal. Demikian juga halnya mengenai pembaharuan hibah. 
Media Komunikasi dan Informasi Hukum dan Masyarakat

Suatu hibah tidak dapat dilakukan pembaharuan dikemudian hari dengan suatu akta notaris. Artinya, suatu hibah yang semula diperbaharui dan disempurnakan dengan akta notaris di belakang hari. Pembaharuan demikian tidak bisa berlaku sejak penghibahan semula.

\subsection{Menurut Hukum Islam}

Hibah, hadiah, dan wasiat adalah istilah-istilah syariat yang sudah menjadi perbendaharaan bahasa Indonesia, sehingga istilah-istilah ini bukan lagi suatu yang asing. Hibah, hadiah dan wasiat merupakan bagian dari tolong menolong dalam kebaikan yang diperintahkan agama islam. Dalam hukum Islam, seseorang diperbolehkan untuk memberikan atau menghadiahkan sebagian harta kekayaan ketika masih hidup kepada orang lain. Pemberian semasa hidup itu sering disebut sebagai hibah.

Kata hibah berasal dari bahasa Arab dari kata (النهَيُة) yang berarti pemberian yang dilakukan seseorang saat dia masih hidup kepada orang lain tanpa imbalan (pemberian cuma-cuma), baik berupa harta atau bukan harta. Diantaranya kata ini digunakan dalam firman Allâh Azza wa Jalla.

Didalam Hukum Islam dipebolehkan untuk seseorang memberikan atau menghadiahkan sebagian atau seluruhnya harta kekayaan ketika masih hidup kepada orang lain disebut "intervivos". Pemberian semasa hidup itu sering disebut sebagai "hibah". Di dalam hukum islam Jumlah Harta seseorang yang dapat dihibahkan itu tidak dibatasi. Berbeda halnya dengan pemberian seseorang melalui surat wasiat yang terbatas pada sepertiga dari harta peninggalan yang bersih.
Terdapat tiga syarat yang harus dipenuhi dalam hal melakukan Hibah Menurut Hukum Islam, yaitu :

1. Ijab, adalah pernyataan tentang pemberian tersebut dari pihak yang memberikan.

2. Qabul, ialah pernyataan dari pihak yang menerima pemberian hibah itu.

3. Qabdlah, merupakan penyerahan milik itu sendiri, baik penyerahan dalam bentuk yang sebenarnya maupun secara simbolis.

Dasar hukum hibah dalam hadist nabi SAW. Antara lain: (Dari Abu Hurairah r.a menceritakan Nabi SAW. Bersabda, "hadiah menghadiahilah kamu, niscaya bertambah kasih sayang sesamamu.!" ( Dari abu hurairah r.a bahwa Rasulullah SAW. Bersabda: "jangan menghina seorang tetangga jika ia memberi hadiah walaupun hanya kuku kambing. ${ }^{20}$

\subsection{Menurut Hukum Adat}

Didalam masyarakat hukum adat, hibah ini dilakukan sewaktu anak-anaknya sudah menikah dan diipisahkan dengan membuatkan rumah, memberikan pekarangan untuk pertanian, ini harus dibedakan dengan Weling (jawa) yang bersifat semacam wasiat. Yaitu sebelum orang meninggal, maka ia mengadakan ketetapan-ketetapan yang ditujukan kepada ahli warisnya atau istrinya. Pertama, ia semasa hidupnya member petunjuk-petunjuk bagaimana harta bendanya akan dibagi waris kalau ia meninggal.

Jadi barang-barangnya itu belum dibagi bagikannya kepada ahli warisnya, melainkan masih dipegangnya, hanya kalau ia meninggal maka pembagian harta peninggalannya harus dilakukan menurut petunjuk-petunjuk tersebut.

${ }^{20}$ Bukhari, Terjemah Shohih Bukhari III, Achmad Sunarto, dkk. hal.577 
Media Komunikasi dan Informasi Hukum dan Masyarakat

Dasar pemberian hibah adalah sebagai koreksi terhadap hukum adat dan untuk memberikan kepastian hukum.

Hibah ada dua macam yaitu :

1. Hibah biasa yaitu pemberian harta kekayaan pada waktu pewaris masih hidup.

2. Hibah Wasiat yaitu pelaksanaannya setelah pewaris meninggal dunia harta tersebut baru diberikan.

\section{Keabsahan Hukum Pihak Pemberi Hibah dan Penerima Hibah Dengan Surat Dibawah Tangan}

Dalam Kitab Undang-Undang Hukum Perdata Bab X Tentang Penghibahan ini berisikan tentang pengertian dan ketentuan umum tentang hibah, kemampuan untuk memberikan dan menerima hibah, cara menghibahkan sesuatu, serta pencabutan dan pembatalan hibah

Hibah atau Pemberian dalam hal ini sebenarnya termasuk dalam pengertian hukum, karena mempunyai ketentuan-ketentuan hukum sendiri. Pada umumnya proses memberi itu terjadi secara terpisah, yaitu tidak terjadi pada saat yang bersamaan melainkan ada tenggang waktu tertentu sesuai dengan suasana saat itu, jadi sifat dari pemberian itu adalah umum, karena baik pemberi maupun penerima tidak perlu memenuhi kewajiban tertentu kecuali ada kerelaan para pihak dan tidak melihat status individunya. Hibah tanah merupakan pemberian seseorang kepada orang lain dengan tidak ada penggantian apapun dan dilakukan secara suka rela, tanpa ada kontraprestasi dari pihak penerima pemberian, dan pemberian itu dilangsungkan pada saat si pemberi hibah masih hidup. Ini berbeda dengan wasiat, yang mana wasiat diberikan sesudah si pewasiat meninggal dunia. ${ }^{21}$

Ada beberapa orang tertentu yang sama sekali dilarang menerima penghibahan dari penghibah, yaitu:

1. Orang yang menjadi wali atau pengampun si penghibah.

2. Dokter yang merawat penghibah ketika sakit

3. Notaris yang membuat surat wasiat milik si penghibah.

\section{Kedudukan Hukum Berdasarkan Pemberian Hibah Dibawah Tangan}

Dalam Proses peralihan atau pemindahan hak atas tanah karena hibah, pihak yang mengalihkan harus mempunyai hak dan kewenangan untuk memindahkan hak, sedangkan bagi pihak yang menerima hak harus memenuhi syarat sebagai pemegang hak atas tanah yang baru. ${ }^{22}$

Fungsi akta notaris dalam hibah bukan semata-mata sebagai alat bukti, tapi juga sebagai syarat esensial untuk sahnya persetujuan hibah. Karena itu hibah yang tak diperbuat dengan akta notaris, atau hibah yang diperbuat dengan cara bebas di luar akta notaris, adalah persetujuan hibah yang mutlak batal. Demikian juga halnya mengenai pembaharuan hibah.

Suatu hibah tidak dapat dilakukan pembaharuan dikemudian hari dengan suatu akta notaris. Artinya, suatu hibah yang semula diperbaharui dan disempurnakan dengan akta notaris di belakang hari. Pembaharuan demikian tidak bisa berlaku sejak penghibahan semula.

${ }^{21}$ Chairuman Pasaribu dan Suhrawadi K Lubis."Hukum Perjanjian Dalam Islam", Sinar Grafika Cetakan Kedua, Jakarta, 1996, hal. 113.

$22 \mathrm{https}: / /$ santussehandi.wordpress.com, peralihan-hak-milik-atas-tanah-karena-hibah 
Media Komunikasi dan Informasi Hukum dan Masyarakat

Akta dibawah tangan ialah akta yang sengaja dibuat untuk pembuktian oleh para pihak tanpa bantuan dari seorang pejabat. ${ }^{23}$

Ketentuan Pasal 1878 KUH Perdata terdapat kekhususan akta dibawah tangan, yaitu akta harus seluruhnya ditulis tangan si penanda tangan endiri, atau setidak-tidaknya, selain tanda tangan, yang harus ditulis dengan tangannya si penanda tangan adalah suatu penyebutan yang memuat jumlah atau besarnya barang atau uang yang terhutang. Apabila ketentuannya tidak dipenuhi, maka akta tersebut hanya sebagai suatu permulaan pembuktian dengan tulisan. ${ }^{24}$

Sedangkan akta hibah menurut hukum positif dalam hukum perdata alat bukti tertulis atau surat tercantum dalam Pasal 138,165,167 HIR/Pasal 164, 285-305 R.bg dan Pasal 18671894 BW serta Pasal 138-147 RV. Pada asasnya di dalam persoalan perdata (hibah), alat bukti yang berbentuk tulisan itu merupakan alat bukti yang diutamakan atau merupakan alat bukti yang nomor satu jika dibandingkan dengan alat-alat bukti lainnya. ${ }^{25}$

\section{B. Pendaftaran Hibah Pada Kantor Pertanahan Yang Bersumber Dari Hibah Dibawah Tangan}

\section{Peralihan Hak Atas Tanah Pada Kantor Pertanahan Berdasarkan Hibah Dibawah Tangan.}

Bahwa Permohonan telah mengajukan permohonan penetapan hibah, permohonan mana telah terdaftar di Kepaniteraan Pengadilan Agama Medan tanggal 22 Nopember 2017

${ }^{23}$ Sudikno Mertokusumo, Op. Cit,hal. 105

24 Teguh Samudera, Hukum Pembuktian dalam Acara Perdata, Jakarta:Alumni, 1992, hal.45

${ }^{25} \mathrm{Ibid}$, hal. 36 dengan Register perkara permohonan Nomor 125/Pdt.G/2017.Mdn.

1. Permohonan adalah adik kandung dari almarhum Buyung Tanjung bin Harun Tanjung yang telah meninggal dunia pada tanggal 10 Nopember 2003 di Kuala Lumpur dalam keadaan memeluk Agama Islam dan dikebumikan menurut tata cara syari'at Islam di Kuala Lumpur. semasa hidupnya almarhum Buyung Tanjung bin Harun Tanjung ada menhibahkan kepada Pemohon sebidang tanah seluas 398 M2 berikut banguna rumah tempat tinggal diatasnya yang terletak di Jalan Bromo Gg Taqwa No.10 Kelurahan Tegal Sari II Kecamatan Medan Area, Kota Medan sebagaimana tercantum dalam SHM No.279/Tegal Sari II yang diterbitkan oleh Kantor Pertanahan Kotamadya Medan Pada tanggal 27-7-1999.

2. Penyerahan Hibah Kepada Pemohon Juga diketahui oleh ahli waris almarhum Buyung Tanjung bin Harun Tanjung, kemudian oleh ahli waris Buyung Tanjung bin Harun Tanjung menegaskan dan membenarkan Hibah tersebut, Serta menanyakan pemmberian hibah dari almarhum Buyung Tanjung bin Harun Tanjung kepada Pemohon adalah tidak lebih dari 1/3 (satu pertiga) Harta yang dimiliki oleh almarhum Buyung Tanjung bin Harun Tanjung semasa hidupnya, begitu juga dengan adik kandungnya bernama Hasanuddin Tanjung telah menyatakan tidak keberatan atas hibah yang diberikan oleh Buyung Tanjung bin Harun Tanjung kepada Pemohon

Menyatakan Menetapkan sah menurut hukum Hibah yang dilakukan oleh almarhum Buyung Tanjung bin Harun Tanjung Tanjung 
Media Komunikasi dan Informasi Hukum dan Masyarakat

kepada Pemohon (Erna Wati Binti Harun Tanjung) berupa sebidang tanah seluas 398 M2 berikut banguna rumah tempat tinggal diatasnya yang terletak di Jalan Bromo Gg Taqwa No.10 Kelurahan Tegal Sari II Kecamatan Medan Area, Kota Medan, Sebagaimana tercantum dalam Sertifikat Hak Milik No.279/Tegal Sari II yang diterbitkan oleh Kantor Pertanahan Kotamadya Medan Pada tanggal 27-7-1999 atas nama Buyung Tanjung.

\section{Pendaftaran Peralihan Hak Dengan Hibah Dibawah Tangan Berdasarkan Putusan pengadilan.}

Pengadilan Agama medan kelas I-A dalam perkara perdata 125/Pdt.P/2017/PA.mdn tanggal 03 Januari 2018 telah menerima permohona pemohon dengan penetapan hibah.

Sebelum lahirnya peraturan pemerintah (PP) Nomor 24 tahun 1997, bagi masyarakat yang tunduk kepada KUHPerdata surat hibah dan hibah wasiat harus dibuat dalam bentuk tertulis dari Notaris. ${ }^{26}$ Karena hak milik atas barang yang dihibahkan meskipun diterima dengan sah, tidak beralih kepada orang lain yang diberi hibah, sebelum diserahkan dengan cara penyerahan menurut pasal 612,613,616 KUHPerdata. ${ }^{27}$ Setelah lahirnya Peraturan Pemerintah Nomor 24 tahun 1997, setiap pemberian hibah tanah harus dilakukan dengan akta PPAT. ${ }^{28}$ Prolehan hak atas tanah secara hibah dan hibah wasiat sebaiknya didaftarkan peralihan haknya dikantor pertanahan sebagai bentuk pengamanan hibah tanah. ${ }^{29}$

${ }^{26}$ Pasal 1005 KUHPerdata

27 Pasal 1686 KUHPerdata

28 Pasal 37 ayat (1) dan pasal 39 Peraturan Pemerintah Nomor 24 tahun 1997 tentang Pendaftaran Tanah

29 Wawancara dengan Muhammad lqbal, Notaris Kota medan
Besarnya PPh yang harus dibayar oleh orang pribadi atau badan yang memperoleh penghasilan atas pengalihan hak atas tanah dan bangunan menurut Pasal 4 Peraturan Pemerintah Nomor 48 Tahun 1994 tersebut adalah $5 \%$ (lima persen) dari jumlah bruto nilai tertinggi diantara nilai pengalihan berdasarkan akta pengalihan hak dan NJOP atas tanah dan/atau bangunan.

Berdasarkan Pasal 4 ayat (3) huruf a angka 2 Undang-Undang Nomor 17 Tahun 2000 tentang Undang-Undang PPh yang tidak termasuk objek pajak adalah harta hibaan yang diterima oleh keluarga sedarah dalam garis keturunan lurus satu derajat.

Mengacu pada ketentuan diatas maka yang tidak termasuk sebagai objek PPh adalah hibah yang memenuhi persyaratan :

1. Penerimaan harta hibah adalah keluarga sedarah dalam garis lurus keturunan lurus satu derajat, badan keagamaan atau badan pendidikan atau badan social atau pengusaha kecil termasuk koperasi yang ditetapkan oleh Menteri Keuangan.

2. Hibah yang dilakukan tidak berhubungan dengan usaha,pekerjaan, kepemilikan atau penguasaan antar pihak-pihak yang bersangkutan.

Saat terutangnya pajak atas hibah, dan hibah wasiat adalah terhitung sejak tanggal pembuatan akta, kewajiban membayar pajak bagi penerima hak atas tanah dan/atau bangunan diatur dalam Pasal 9 ayat 1 huruf $h$ Undang-Undang Nomor 21 Tahun 1997 tentang BPHTB, yang diumumkan pada Lembaran Negara tahun 1997, Nomor 44, Tambahan Lembaran Negara Nomor 3688, diundangkan pada tanggal 29 Mei 1997.

Jika pemberian hibah dilakukan dengan surat di bawah tangan, maka hibah peralihan 
Media Komunikasi dan Informasi Hukum dan Masyarakat

hak kepemilikan secara yuridis tersebut baru berlaku saat sudah dibuat suatu Akta Hibah di hadapan Notaris/PPAT yang berwenang.

Jika hibah dibuat tanpa menggunakan akta otentik dan tanpa persetujuan ahli waris maka ketika ahli waris yang tidak menyetujui akta hibah tersebut mengajukan pembatalan dengan cara gugatan maka isi dari akta hibah yang dibuat dengan tidak menggunakan akta otentik tersebut tidak mengikat para pihak lagi.

\section{Kesimpulan Dan Saran}

\section{A. Kesimpulan}

Pembahasan yang telah diuraikan dalam Analisis Yuridis Pemberian Hibah Dibawah Tangan Dikaitkan dengan Pendaftaran Pada Kantor Pertanahan Terhadap (Penetapan Pengadilan Agama Medan Kelas I-A Nomor: 125/Pdt.P/2017/PA.Mdn), Sebagaimana diatas, maka diperoleh beberapa kesimpulan sebagai berikut :

1. Bahwa pemberian hibah dibawah tangan tidaklah sah, karena kapasitas dan kewenangan hibah yang memiliki kekuatan hukum tetap untuk pembuatan akta hibah itu adalah seorang notaris yang di tunjuk pemerintah sebagai pejabat umum yang berwewenang sesuai dengan aturan-aturan yang telah tercantum dalam peraturan pemerintah No.24 tahun 1997 tentang pendaftaran tanah.

2. Tanah yang dihibahkan dibawah tangan menurut hukum islam adalah sah tetapi tidak sah menurut peraturan pemerintah No.24 tahun 1997 tentang pendaftaran tanah karna hibah wajib dilakukan dihadapan notaris

3. Kekuatan pembuktian surat hibah dibawah tangan yang pemberi hibah telah meninggal dunia, dalam proses balik nama tidak dapat dilakukan oleh pihak penerima hibah di kantor Pertanahan. Jadi akta dibawah tangan harus mendapatkan penetapan pengadilan dahulu agar mempunyai kekuatan hukum nantinya bila balik nama kepada penerima hibah.

\section{B. Saran}

Berdasarkan pembahasan yang telah diuraikan dalam Analisis Yuridis Pemberian Hibah Dibawah Tangan Dikaitkan dengan Pendaftaran Pada Kantor Pertanahan Terhadap (Penetapan Pengadilan Agama Medan Kelas IA Nomor: 125/Pdt.P/2017/PA.Mdn), Sebagaimana diatas, maka diperoleh beberapa kesimpulan sebagai berikut :

1. Masyarakan indonesia dalam melakukan penghibahan atau perjanjian yang berkaitaan dengan perbuatan hukum haruslah dilakukan dihadapan notaris agar nantinya tidak menimbulkan perkara di kemudian hari.

2. Perlu adanya kesadaran dari masyarakat Indonesia akan perbuatan hukum yang mereka lakukan jika tidak dilakukan dengan benar maka akan mempersulit semuannya, karna harus sesuai dengan ketentuan perundang-undangan yang berlaku di Indonesia.

3. Apabila masyarakat ingin melakukan peralihan hak milik melalui hibah, karna hukum hibah adalah hukum yang tidak memaksa dan hibah tanah adalah pemberian seseorang kepada orang lain dengan tidak ada penggantian apapun dan dilakukan dengan cara sukarela tanpa adanya kontraprestasi baiknya dilakukan dihadapan notaries atau pejabat yang berwewenang. 
Media Komunikasi dan Informasi Hukum dan Masyarakat

\section{DAFTAR PUSTAKA}

\section{A. Buku}

Abdul Ghofur Anshori, Filsafat Hukum Hibah dan Wasiat Di Indonesia, Gadjah Mada Universty Press, 2018

Ali, Nawawi, Persinggungan Hibah dengan Hukum Kewarisan Islam dan permasalahan permasalahan dalam konteks kewenangan peradilan agama, Jakarta, Al-Hikmah dan DITBINBAPERA Islam, 1998

Anshori A G Seri Hukum Islam : Filsafat Hukum Hibah Dan Wasiat di Indonesia, Gadja Mada University Pres Yogyakarta, 2011

Parlindungan A.P, Pendaftaran Tanah di Indonesia, Mandar Maju : Bandung, 1999

Bambang Sunggono, Metode Penelitian Hukum, Raja Grafindo Persada, Jakarta, 2002

Boedi Harsono, Hukum Agraria Indonesia, Djambatan, Jakarta, 2008

--------------, Hukum Agraria Indonesia. Sejarah Pembentukan UndangUndang Pokok Agraria, Isi dan Pelaksanaannya, Cetakan ke-12., (Jakarta: Djambatan, 2008)

Bukhari, Terjemah Shohih Bukhari III, Achmad Sunarto, dkk

Chairuman Pasaribu dan Suhrawadi $\mathrm{K}$ Lubis."Hukum Perjanjian Dalam Islam" , Sinar Grafika Cetakan Kedua, Jakarta, 1996

Moh. Hatta Bab-bab Tentang Perolehan dan hapusnya Hak Atas Tanah, Liberty, Yogyakarta, 2014

Effendi Perangin, Mencegah Sengketa Tanah, Rajawali Cetakan Kedua, Jakarta, 1990

G.H.S. L.Tobing, Peraturan Jabatan Notaris, Erlangga, Jakarta, 1992

Habib Adjie, Hukum Notaris Indonesia, Refika Aditama, Bandung 2009
JJ M, Wuisman, dengan menyunting M. Hisyam, Penelitian IImu-IImu Sosial, (jilid I), Jakarta, FE UI,1996

Koenjaraningrat, Metode-metode Penelitian Masyarakat, Jakarta, Gramedia, 1997

Masri Singarimbun dan sifian effendi, Metode Penelitian Survei, Jakarta, LP3ES, 1989

M. Solly Lubis, Filsafat IImu dan Penelitian, Mandar Maju Bandung,1994

R. Soepomo, Bab-bab Tentang Hukum Adat, Cetakan ke-14 (Jakarta: PT Pradnya Paramitha, 1994)

R. Subekti dan R. Tjitrosudibyo, Kitab Undang-Undang Hukum Perdata, (Jakarta: Rineka Cipta), 1992

Aneka Perjanjian, (Bandung: Alumni, 1985)

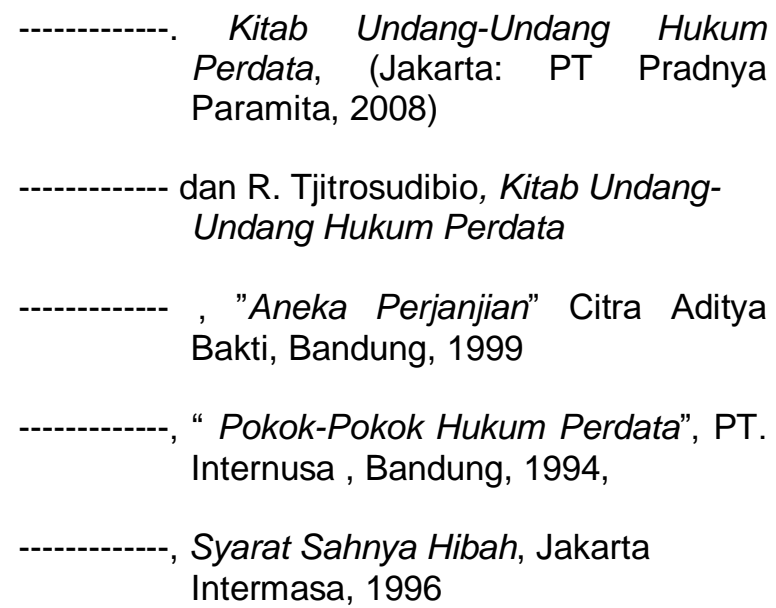

Ropaun Rambe, Hukum Acara lengkap

Santoso, Urip Pendaftaran dan peralihan hak atas tanah, Kencana Predana Media, Jakarta, 2010

Sudikno Mertokusumo, Mengenal Hukum sebagai Suatu Pengantar, Liberty, Yogyakarta, 2005

Hukum, Liberty, Yogyakarta, 2010

\section{Hukum Acara Perdata} Indonesia,Yogyakarta: Liberty Yogyakarta, 2006

Agraria -, Hukum dan Politik Terbuka : Jakarta, 1988 
Media Komunikasi dan Informasi Hukum dan Masyarakat

Sumadi Suryabrata, Metode Penelitian, Jakarta, Raja Grafindo Persada, 1998

Sutedi Adrian, SH, MH, Peralihan Hak Atas Tanah dan Pendaftarannya, Sinar Frafika, Jakarta, 2014

Soerjono Soekarto dan Sri Mamudji, Penelitian Hukum Normatif suatu Tinjauan Singkat, Jakarta, PT Raja Grafindo Persada, 1995

, Penelitian Hukum Normatif ,cetakan kelima, Jakarta, PT Raja Grafindo Persada, 2001 -, Pengantar Penelitian Hukum, UI Press, Jakarta, 1986

Tanpil Ansari Siregar, Metodologi Penelitian Hukum, Medan, Medan Grafika, 2004

Teguh Samudera, Hukum Pembuktian dalam Acara Perdata, Jakarta:Alumni, 1992

Urip Santoso, Hukum Agraria dan Hak-hak Atas Tanah, Prenada Media Group ,2005

Widya Anggraeni, Tanggung Gugat Pemberi Hibah Akibat Pembatalan Hibah, Universitas Airlangga, Surabaya, 2006

Wiwik Afifah, Peralihan Hak Atas Tanah,https:/wiwik e45.wordpress.com

\section{B. Undang-Undang}

\section{Internet}

Departemen Agama RI, Al-Quran dan Terjemahnya

Umi Rochayatun, http://umiro chayatun,tentang hibah.html

hibah".html

blogspot.co.id"unsur-unsur

Santus sehandi.wordpress.com, peralihan-hakmilik-atas-tanah-karena-hibah Read more https: // konsultasi syariah.com/ 33907- membagi- waris- sebelummeninggal. html 